\author{
JURNAL PENJAMINAN MUTU \\ LEMBAGA PENJAMINAN MUTU \\ INSTITUT HINDU DHARMA NEGERI \\ DENPASAR
}

Volume 5 Nomor 2 Agustus 2019

ISSN : 2407-912X (Cetak)

ISSN : 2548-3110 (Online)

http://ejournal.ihdn.ac.id/index.php/JPM

\title{
PEMBELAJARAN BERBASIS MULTIMEDIA: DALAM MEMAHAMI KEBERAGAMAN GAYA BELAJAR ANAK
}

\author{
Oleh \\ Harpan Reski Mulia \\ Madrasah Ibtidaiyah Negeri 11 Kutacane, Aceh Tenggara \\ harpanreskimulia@gmail.com \\ diterima 08 Juli 2019, direvisi 27 Agustus 2019, diterbitkan 31 Agustus 2019
}

\begin{abstract}
This writing discusses about a way to understand the varieties of children's learning styles in environment of formal school. One of the ways that will be discussed is by designing a learning based on multimedia. The research uses an approach which vies some concepts existed in the variable. It is called by library research. The result of this research shows that children's learning styles generally are divided into three styles, they are auditory, visual, and kinesthetic. By using multimedia approach in teaching, it will help teacher in understanding various styles of children's learning. It is because of multimedia consist of the components, such as media and audio media and visual media have been integrated in multimedia. Instead of multimedia which is designed well can stimulate children's attention in learning process so the children are interested to follow the learning and all of aspects that are needed by children.
\end{abstract}

\section{Keywords: learning, multimedia, learning style}

\section{PENDAHULUAN}

Perbedaan individu (Student differences) sering tidak dihiraukan. Salah satu perbedaan individu yang kerap luput dari perhatian lembaga pendidikan adalah perbedaan siswa dalam belajar atau gaya belajar siswa (learning style). Gaya belajar ini penting untuk diperhatikan, karena gaya belajar siswa adalah cara yang menjadi karasteristik siswa dalam memahami, memproses dan memformulasikan informasi yang disampaikan oleh guru (Tsingos, BosnicAnticevich, \& Smith, 2015). Dengan demikian, perlu perhatian khusus dalam memahami perbedaan gaya belajar siswa agar pembelajaran lebih efektik dan siswa bisa lebih mudah untuk menangkap pembelajaran yang disampaikan.

Secara jenis kelamin, tidak menjadi penyebab seorang anak memiliki tipe gaya belajar tertentu (Yuniawatika, 2018), demikian juga golongan darah, juga tidak mempunyai hubungan spesifik dengan gaya belajar seseorang (Rosyidah, 2017). Namun, yang menjadi poin penting adalah setiap anak mempunyai cara tersendiri dalam belajar. Ketika gaya belajar ditinjau dari sensori, para ahli berpendapat ada tiga jenis 
gaya belajar yaitu dengan melihat (visual), mendengan (auditori), dan praga (kinestetik) (DePorter \& Mike, 2010:110).

Melihat beragamnya gaya belajar siswa, maka seogiyanyalah pendidik dapat memberikan sebuah pembelajaran yang integral dalam memfasilitasi siswa dalam belajar, karena ketiga gaya belajar tersebut juga berpengaruh secara signifikan dalam prestasi belajar mereka (Bire, Geradus, \& Bire, 2014). Tugas pendidik bukan hanya sekadar menyampaikan materi saja tanpa menghiraukan bagaimana hasilnya, peserta didik dapat memahami atau tidak bukan suatu hal yang penting. Hal semacam ini bukanlah guru yang diinginkan oleh semua lembaga pendidikan, bahkan sudah menjadi tanggung jawab bagi semua guru berupaya agar materi yang disampaikan dapat diterima dan dipahami oleh siswa bahkan dapat diaplikasikan dalam kehidupan sehari-hari mereka.

Salah satu upaya yang dapat dilakukan adalah mendesain pembelajaran yang bisa memahami gaya belajar anak tersebut, yaitu menentukan media pembelajaran yang tidak berpihak pada satu gaya belajar seperti gaya belajar audio saja. Namun, media pembelajaran yang digunakan oleh pendidik harus dapat memahami semua gaya belajar peserta didik. Oleh pakar media pembelajaran, memberikan satu solusi yaitu multimedia (multimedia learning). Sebagaimana multimedia learning yakni menggabungkan teks, seni, suara, gambar, dan video. Multimedia ini menarik perhatian penulis untuk dikaji dan dianalisis dengan harapan dapat menjadikan sebagai salah satu alternatif bagi pendidik dalam upaya memahami keberagaman gaya belajar peseta didik.

Sebagaimana banyak kajian menunjukkan, bahwa mutimedia learning terbukti dapat meningkatkan prstasi belajar siswa (Butcher, 2006; Mayer, Bove, Bryman, Mars, \& Tapangco, 1996; Moreno \& Mayer, 1999; Moreno \& Valdez, 2005). Karena, multimedia learning meurut Mayer (2009:9) memiliki modalitas sensori yaitu lebih fokus ke alat penerimaan indrawi yang digunakan siswa untuk menagkap materi-materi seperti mata dan telinga. Lebih rinci tentang pengaruh multimedia ini terhadap penguasaan konsep dalam peneitian Gunawan, Dkk (2016) yang merupakan jenis penelitian educational reasearh and development, menunjukkan bahwa multimedia learning terbukti dapat membantu mahasiswa dalam memahami konsep fisika dengan baik.

Dari latar belakang tersebut maka fokus diskusi pada tulisan ini adalah tentang memahami gaya belajar siswa dengan multimedia. Sehingga tujuan dari tulisan ini adalah memberikan struktur tentang multimedia yang dapat digunakan untuk memahami keberagaman gaya belajar anak.

\section{PEMBAHASAN}

\section{Konsep Dasar Multimedia Learning}

Secara sederhana, multimedia itu dapat ditinjau dari dua persfektif, yaitu multimedia sebagai kata benda dan multimedia sebagai kata keterangan. Ketika multimedia diartikan sebagai kata benda maka multimedia itu merujuk pada alat teknologi untuk menyajikan materi dalam bentuk verbal dan visual. Namun, ketika ditinjau multimedia itu sebagai kata keterangan, maka multimedia dapat diartikan bahwa anak belajar dari media yang disadikan dari gabungan katakata dan gambar atau menyajikan pesan yang melibatkan kata-kata dan pesan (Mayer, 2009:4).

Pada awal perkembangannya, multimedia lebih didefinisikan dan dianggap sebagai kata benda, atau lebih memusatkan kepada penggunanan alat teknologinya, seperti gabungan dari komputer, spekear, infokus atau lain sebagainya. Sehingga, jenis isu yang diangkat lebih melibatkan media, yaitu menentukan teknologi mana yang paling efektif untuk menyampaikan informasi. Namun, pendekatan yang lebih berpusat teknologi ini adalah sesuatu yang keliru, sebagaimana penelitian Cuban menunjukan bahwa pendekatan semacam ini gagal membawa ke perkembangan abadi dalam pendidikan (Larry Cuban, dalam Mayer, 2009: 12). 
Lebih lanjut, Cuban menyatakan bahwa kegagalan ini disebabkan karena kurangnya keterlibatan guru yang pada akhirnya teknologi dijadikan sebagai agen utama dalam proses pengajaran, tidak mengherankan bahwa penggunaan teknologi telah bertemu dengan keberhasilan yang relatif sedikit di dalam kelas (Provenzo, 1986). Dengan kata lain, guru tidak perlu lagi hadir tetapi bisa saja melalui media rekaman yang disiarkan melalui radio atau televisi sudah cukup. Hasil penelitian dari Cuban ini juga membantah pernyataan dari Thomas Edion yang mengatakan bahwa "gambar gerak ditakdirkan untuk merevolusi sistem pendidikan, dalam beberapa tahun kedepan.

Sejalan dengan Cuban, Cognition and Technology Group (dalam Mayer, 2009: 14) menunjukkan bahwa dua sistem terbesar berbasis komputer pada tahun 1970-an yaitu PLATO dan TICCIT gagal menghasilkan pembelajaran yang lebih baik daripada pembelajaran yang dilakukan dengan sistem instruksional tradisional yang dibimbing guru. Mayer dengan gamblang memberikan argumen bahwa, jika multimedia masih dipahami sebagai alat, dengan pendekatan kepada teknologi, maka bersiaplah untuk mendapatkan hasil-hasil yang mengecewakan, sebagaimana pendekatan pada teknologi ini sudah mempunyai sejarah kegagalan 100 tahun (Mayer, 2009: 15).

Beranjak dari multimedia yang diartikan sebagai kata benda, maka opsi kedua adalah multimedia dipahami sebagai kata keterangan, yaitu menyajikan informasi dengan kata-kata dan gambar melalui media, artinya multimedia disini dipahami sebagai sarana untuk menampilkan pesan yang terdiri dari kata-kata, suara, animasi, video dan lain sebagainya, bukan dengan menggunakan beberapa media. Pada pengertian ini medianya bisa saja hanya satu, tetapi multi disini adalah bentuk pesannya, seperti teks, gambar dan lain sebagainya.

Wina Sanjaya (2012:219) memberikan pengertian dari multimedia pembelajaran yaitu sebagai pembelajaran yang di desain dengan menggunakan berbagai media secara bersamaan seperti teks, gambar (foto), film (video) dan lain sebagainya yang kesemuanya saling bersinergi untuk mencapai tujuan pembelajaran yang di rumuskan sebelumnya. Dilihat dari pengertian yang diberikan Sanjaya ini, maka multimedia disini adalah gabungan dari beberapa alat untuk menyampaikan pesan yaitu gabungan dari teks, gambar, audio dan lain sebagainya.

Sejalan dengan pendapat Sanjaya diatas, Tay Vaughan (2010: 1) memberikan pengertian bahwa multimedia merupakan kombinasi teks, seni, suara, gambar, dan video yang disampaikan dengan komputer atau di manipulasi secara digital dan dapat disampaikan atau dikontrol secara interaktif.

Demikian juga Rudi dan Cepi (2007: 21), mengatakan bahwa multimedia merupakan suatu sistem penyampaian dengan menggunakan berbagai jenis bahan belajar yang membentuk suatu unit atau paket. Contohnya suatu modul belajar yang terdiri atas bahan cetak, bahan audio, dan bahan audio visual.

Menilik pengertian yang diutarakan oleh Sanjaya, Rudi dan Cepi diatas, maka secara sederhana dapat dipahami bahwa multimedia merupakan gabungan dari beberapa media pembelajaran yang dikombinasikan (contoh: gambar dan suara) yang bekerja secara sinergis untuk mencapai tujuan pembelajaran yang ditentukan. Disinilah letak, dimana multimedia sangat menunjang pada proses pembelajaran, karena fokus dari multimedia adalah menggunakan teknologi sebagai alat bantu untuk memahami pembelajaran.

Multimedia yang ditinjau sebagai kata keterangan ini akan lebih menguntungkan terhadap proses pembelajara. Karena, pendekatan yang digunakan adalah multimedia dengan pendekatan berpusat kepada siswa. Artinya ketika menggunakan multimedia, maka seogianya pendidik melihat terlebih dahulu apakah siswa dalam memperoleh informasi lebih mudah dengan audio, visual atau lain sebagainya. Dengan demikian menurut Mayer (2009), jika beberapa media untuk penyampaian pembelajaran di desain dan digabungkan 
menjadi sesuatu yang inheren, maka pembelajaran akan lebih efektif.

\section{Pengembangan Multimedia Learning}

Dewasa ini, multimedia berkembang dengan mengikuti fungsinya. Perkembangan multimedia jika dilihat dari pengembangannya pada beberapa komponen tersebut, maka multimedia dapat dibagi menjadi dua jenis, yaitu multimedia linier dan multimedia interaktif:

1. Multimedia linier:

Multimedia jenis ini merupakan multimedia yang bersifat sekuensial atau berurutan, setiap siswa atau pemakai multimedia berjenis ini menggunakannya sesuai dengan urutan setahap demi setahap sesuai dengan pengemasan materi yang ditentukan, siswa belajar berdasarkan bagian-bagian yang didesain sedemikian rupa secara berurutan dengan waktu yang telah ditentukan (Munir, 2013: 289).

Multimedia linear ini tidak memiliki alat kontrol, dimana dapat digunakan pada saat menggunakannya, sehingga tampilan yang akan dijelaskan berjalan sendiri sesuai dengan urutan yang telah di program atau dengan kata lain pada saat penggunaannya yang telah diprogram tersebut hanya bisa disaksikan sampai waktu limit yang telah ditentukan oleh orang yang membuat program tersebut, contoh dari multimedia jenis linier ini adalah TV dan film.

2. Multimedia interaktif

Multimedia interaktif sebagaimana diungkapkan oleh Munir (2013: 110) adalah merupakan tampilan media yang dirancang oleh desainer agar tampilannya memenuhi fungsi menginformasikan pesan dan memiliki interaktifitas kepada pengguna (user) dan oleh Munadi (2013: 152) menyatakan bahwa multimedia interaktif ini merupakan yang diprogram atau dirancang untuk dipakai siswa secara individu (belajar mandiri). Saat siswa mengaplikasikan program ini, ia diajak untuk terlibat secara auditif, visual, kenetic, sehingga dengan peliatan ini dimungkinkan informasi atau pesannya mudah dimengerti.

Contoh dari multimedia interaktif ini adalah komputer, pada saat siswa menggunakan komputer maka siswa akan berinteraksi dengan komputer dalam bentuk teks, gambar, audio, video dan lain sebagainya. Sehingga siswa dapat dengan leluasa mengontrol saat penggunaannya seperti saat menggunkan teks pada Microsoft Word, Exel, Power Point dan lain sebagainya jika terjadi kesalahan atau ingin melihatnya lagi maka siswa dapat membaca atau menghapus pada bagian yang dimaui. Demikian juga pada Video maka siswa dapat menjeda memperlambar pada part yang dikehendaki. Demikian gambaran tentang multimedia interaktif ini.

Di samping itu pembelajaran berbasis multimedia telah memberikan kontribusi yang sangat besar dalam proses pembelajaran, hal ini telah banyak penelitian menunjukkan bahwa penggunaan multimedia memberikan kontribusi terhadap pemahaman siswa pada berbagai tema dalam meningkatkan pemahamannya seperti penelitian Irwan (2017) terhadap siswa Kelas XI B Farmasi SKM Guna Darma Nusantara. Objek studinya tidak begitu luas hanya pada tema kemampuan mengklasifikasi tumbuhan sebagai obat tradisional. Penelitian ini menunjukkan bahwa dengan menggunakan multimedia dapat meningkatkan kemampuan siswa untuk mengklasifikasikan tumbuhan sebagai obat tradisional yang pada awalnya nilai siswa rata-rata siswa sebelum mendapatkan pembelajaran dengan menggunakan multimedia belum mencapai KKM atau 54.30. Namun, setelah diberikan perlakuan pembelajaran dengan menggunakan multimedia meningkat menjadi 74.59. Multimedia presentasi prezi dan multimedia power point juga 
mempunyai interaksi dengan gaya belajar anak, yaitu bahwa multimedia presentasi maupun multimedia power point anak yang bergaya belajar kinestetik memiliki kemampuan mengingat konsep yang lebih tinggi dibandingkan anak yang bergaya belajar auditori, maupun, dan anak yang memiliki gaya belajar auditori memilki kemampuan mengingat konsep yang lebih tinggi dibandingkan anak yang memiliki gaya belajar visual, demikian kesimpulan dari Muh. Rais (2015). Selain itu sebuah studi eksperimen juga telah pernah dilakukan oleh Zang (2005), eksperimen yang dilakukannya adalah tentang interactive Multimedia Based E-Learning, hasil eksperimen pertama dan kedua terhadap mahasiswa di sebuah Universitas di Amerika menunjukkan bahwa dengan waktu belajar yang sama, mahasiswa yang diperlakukan dengan pembelajaran e-learning interaktif berbasis multimedia mendapatkan nilai yang lebih tinggi dan juga tingkat kepuasan yang lebih tinggi daripada kelas tradisional.

\section{Kenapa Multimedia Learning?}

Sebagaimana telah diutarakan pada pembahasan sebelumnya, bahwa multimedia itu bisa menggabungkan antara teks, gambar, audio dan lain sebaginya. Demikian juga pada gaya belajar anak yang terdiri gaya belajar audio, visual dan kinestetik. Maka, ketika multimedia yang didesain itu mengandung unsur gambar atau teks (bagi visual) dan suara (bagi auditori), akan memudahkan bagi anak dalam proses pembelajar, bahkan eksperimen yang dilakukan Moredo dan Valdes (Moreno \& Valdez, 2005) pembelamenunjukkan bahwa pembelajaran dengan menggunakan multimedia yang mengandung unsur teks dan suara lebih efektif daripada hanya mengandung teks saja atau suara saja.

Pada dasarnya banyak gaya belajar seseorang, ada anak yang cenderung mendengarkan saja, ada pula anak yang cenderung lebih suka belajar dengan langsung memperagakannya, dan tak luput juga, gaya anak dalam belajar lebih pada memperhatikan dengan detail. Hal inilah yang perlu diperhatikan seorang guru agar pembelajaran yang disampaikan dapat membekas kepada peserta didik. Bahkan Adi. W. Gunawan (dalam Suryadi, 2010: 55) mengklasifikasikan gaya belajar anak menjadi 5 (Lima) macam yaitu, Visual (penglihatan), auditori (pendengaran), kinestetik (gerakan), olfactory (penciuman), dan gustatory (pengecapan).

Adapun Bobbi, dkk (2008: 168) menyatakan bahwa gaya belajar itu ada tiga, yaitu:

\section{Visual}

Gaya belajar visual sebagaimana diungkapkan oleh Bobbi (dalam Suryadi, 2010: 58) adalah cara atau model belajar dengan penampakan atau visualisasi. Pada buku lain Bobbi (2008:68) mengungkapkan bahwa anak pada tipe gaya belajar visual ini harus didorong membuat banyak simbol dan gambar dalam catatan mereka. Karena, para pelajar visual belajar terbaik saat mereka mulai dengan gambaran keseluruhan.

Hamzah (2008: 181) lebih lanjut menjelaskan bahwa karakteristik yang khas bagi para anak yang menggunakan gaya belajar visual adalah:

a. Kebutuhan melihat sesuatu (informasi/pelajaran) secara visual untuk mengetahui atau memahaminya;

b. Memiliki kepekaan yang kuat terhadap warna;

c. Memiliki pemahaman yang cukup terhadap masalah artistik;

d. Memiliki kesulitan dalam berdialog secara langsung;

e. Terlalu reaktif terhadap suara;

f. Sulit mengikuti anjuran secara lisan;

g. Sering salah menginterpretasikan kata atau ucapan.

2. Audio 
Adapun gaya belajar audio ini adalah cara atau model belajar dengan menggunakan indra pendengaran (Suryadi, 2010:60). Para pelajar auditorial mungkin lebih suka merekam pada kaset dari pada mencatat. Pelajar auditorial juga ada yang suka belajar sambil mendengarkan musik dan catatan penting yang dikemukakan Bobbi (2008) adalah pelajar auditorial harus diperbolehkan berbicara dengan suara perlahan pada diri mereka sendir.

Ada beberapa karakteristik anak yang mempunyai gaya belajar audio ini, pertama informasi hanya bisa diserap melalui pendengaran, kedua memiliki kesulitan untuk menyerap informasi dalam bentuk tulisan secara langsung, ketiga memiliki kesulitan menulis ataupun membaca (Hamzah, 2008: 182).

3. Kinestetik

Berlain dengan dua gaya belajar di atas, gaya belajar kinestetik ini adalah metode atau model belajar dengan gerakan (Suryadi, 2010:61). Pelajarpelajar dengan gaya kinestetik ini menyukai proyek terapan. Para pelajar kinestetik suka belajar melalui garakan dan paling baik menghafal informasi dengan mengasosiasikan gerakan dengan setiap fakta. Nah, terhadap pendidik disarankan agar mendorong siswa untuk dapat menerapkan semua metode ini dalam belajar atau mungkin juga ingin memberi tahu cara orang tua tentang tipe belajar si anak dan mengajarkan mereka strategi yang mendukung gaya belajar tersebut (Bobbi, 2008).

Bagi anak dengan gaya belajar kinestetik ini ada beberapa karakteristik, yaitu:

a. Cenderung menempatkan tangan sebagai alat penerima informasi utama agar dapat terus mengingatnya; b. Hanya dengan memegang bisa menyerap informasinya dan tanpa harus membaca penjelasannya;

c. Dalam pembelajaran cenderung tidak bisa/tahan duduk terlalu lama untuk mendengarkan pelajaran;

d. Lebih menyukai jika pembelajaran disertai dengan kegiatan fisik;

e. Memiliki kemampuan mengoordinasikan sebuah tim dan kemampuan mengendalikan garak tubuh (athletic ability)

Gaya belajar anak ini sangat mempengaruhi pemahamannya terhadap materi yang disampaikan. Ketika anak yang gaya belajarnya auditori, guru dalam pembelajaran hanya menyuruh menulis dan memahaminya sendiri terhadap apa yang telah ditulisnya, kemudian memberikan tes kemungkinan besar nilai tes yang diperoleh anak tersebut akan rendah, begitu juga anak yang gaya belajarnya visual ketika diberikan ceramah saja, atau dengan menggunakan alat audio sebagai penyampaian bahan ajar akan cenderung bernasib sama dengan anak yang diperlakukan tidak sesuai dengan gaya belajarnya, demikian urgen gaya belajar dalam mencapai keberhasilan dalam belajar.

Dari penjelasan tentang gaya belajar anak, yakni dengan beberapa sensoris, jika dipandang pada multimedia penyampaian informasi, sangat sesui dengan alat sensor yang digunakan anak dalam menangkap informasi (materi pelajaran). Selain itu, menurut Mayer (2009: 63) konsepsi multimedia learning juga selalu diatur dan disesuaikan dengan cara kerja otak manusia bekerja dalam mengambil informasi (pembelajaran). Ada tiga asumsi dasar tentang kesesuaian multimedia dengan cara kognitif dalam menangkap dan memproses informasi yang diterima (Mayer, 2009: 6892), yaitu:

1) Asumsi saluran ganda

Manusia, pada berdasarkan asumsi ganda ini, dianggap memiliki saluran terpisah dalam memproses informasi visual dan materi audittori. Saat informasi 
disajikan ke mata (seperti video dan lain sebagainya yang mengadung unsur visual dan audio), maka manusia memulai memproses informasi itu ke saluran visual dan saat informasi itu didapakan memalui telinga berupa suara, manusiapun memprosesnya dalam saluran auditori.

Dengan demikian, dua alat sensor yang dimiliki oleh manusia tersebut bekerja secara bersamaan dalam mengambil dan memproses informasi yang didapatkan, sehingga keuntungan yang didapatkan adalah lebih banyak informasi yang didapkan tanpa memberikan efek atau gangguan kepada alat sensor yang satu dengan yang lain.

2) Asumsi kapasitas terbatas

Asumsi yang kedua ini, beranggapan bahwa manusia punya keterbatasan atas jumlah informasi yang bisa diproses dalam masing-masing saluran pada suatu waktu tertentu (Mayer, 2009: 72). Misalnya, ketika informasi yang bisa diterima oleh mata itu hanya tiga pada satu waktu, apabila dalam pembelajaran tersebut menggunakan multimedia yang memuat audio dan visual, siswa bisa lebih banyak menangkap imformasi yang diberikan. Karena, pada tataran kognitif pemprosesan yang terima melalui mata berbeda dengan imformasi yang di terima oleh telinga (melalui audio).

Keterbatasan kapasitas ini kemudian dapat digunakan dengan multimedia, agar pembelajaran tidak jenuh dan membosan. Sweller dan Chander (1994) ( dalam Mayer, 2009:73) memberikan agumen bahwa masing-masing unsur dalam materi dapat dipelajari secara terpisah dan gampang, karena di dalam kognitif berbeda tempat dalam memproses informasi yang diterima melalui alat indra manusia.

3) Asumsi pemprosesan aktif

Manusia secara aktif melibatkan diri dalam pemprosesan aktif untuk mengkonstruk representasi mental yang saling terkait terhadap pengalaman yang dirasakan, demikian menurut asumsi pemprosesan aktif (Mayer, 2009:74), dengan artian bahwa manusia itu bukan prosesor pasif yang hanya menambah sebanyak-banyaknya informasi kedalam memorinya sebagaimana manusia dalam anggapan teori tabularasa.

Dari asumsi pemprosean aktif ini, dapat diambil kesimpulan bahwa pembelajaran aktif sangat bermanfaat jika pendidik dapat bisa mengetahui cara khas yang digunakan siswa dalam mengambil informasi (gaya belajar) apakah dia melalui visual, audio atau kinestetik. Dengan demikian, multimedia sangat bermanfaat dalam memahami gaya belajar siswa, karena hubungannya yang begitu erat dalam mendapatkan informasi yaitu materi pelajaran.

\section{Merancang Pembelajaran Berbasis Multimedia}

Pembelajaran berpusat pada siswa (Student Centre) memberikan kewajiban yang mendasar kepada pendidik agar bisa melatih siswa untuk belajar secara mandiri termasuk dalam memberikan dasar pengetahuan untuk dapat mendesain pembelajaran. Pendidikan memfasilitasi siswa dalam proses pembelajaran, termasuk perlengkapan yang akan digunakan dalam berlangsungnya pembelajaran. Penjelasan awal menunjukkan bahwa PBM harus mampu menyajikan berbagai pengalaman belajar yang sesuai dengan karakter anak, oleh karenanya pendidik dituntut mampu mengkombinasikan dan mengkonstruksi berbagai media pembelajaran yang akan diterapkan dalam pembelajaran. Media pembelajaran tersebut yang digunakan yaitu bisa saja kombinasi dari tulisan, suara dan anime yang bergerak sehingga memberikan pengalaman yang baik bagi peserta didik.

Hasil penelitian menunjukkan bahwa pendidikan berbasis multimedia mempengaruhi kompetensi siswa menggunakan konsep fungsional dibandingkan dengan metode pengajaran tradisional, multimedia secara positif juga mempengaruhi penggunaan konsep siswa, serta multimedia juga dapat mempengaruhi sikap siswa dalam menerima pembelajaran 
demikian hasil penelitian yang dilakukan oleh Beydogan \& Zelnel Hayran (2015). Penelitian ini juga sejalan dengan penelitian yang dilakukan oleh Mayer (2009: 107-115) menunjukkan bahwa multimedia yang digunakan dalam pembelajaran dapat bekerja dan memberikan hasil yang lebih baik dalam pembelajaran, serta bahwa dengan menambahkan ilustrasi pada teks atau menambah animasi pada narasi maka itu lebih bisa membantu peserta didik dalam memahami materi yang diasajikan. Seperti contohnya dengan multimedia effect, menyajikan dengan kata-kata dan gambar bisa menghasilkan pembelajaran lebih baik daripada menyajikan dengan kata-kata saja.

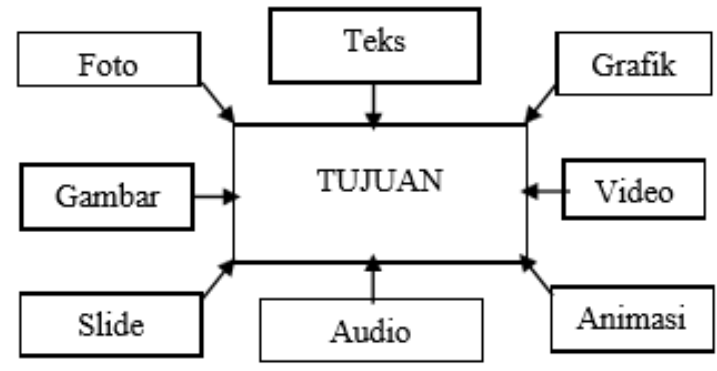

Tabel I: Bahan Dasar Multimedia dalam Wina Sanjaya (2014:220)

Multimedia yang didesain dalam pembelajaran mempunyai manfaat yang baik dalam pembelajaran, karena selain memadukan beberapa unsur media yang terkontrol untuk mencapai tujuan pembelajaran, juga multimedia yang dibuat tersebut dilaksanakan melalui perencanaan yang matang. Perencanaan yang matang ini lah semua aspek yang digunakan akan menggunakan rancangan pembelajaran ini mempertimbangkan, terutama dalam keberagaman gaya belajar siswa karena hal inilah salah satu tujuan dari multimedia yang dalam pembelajaran.

Dilihat pada bagan di atas bahwa multimedia memadukan beberapa media pembelajaran, seperti media foto hal ini sangat bermanfaat bagi peserta didik yang mempunyai gaya belajar audio, begitu juga media pembelajaran audio yang sangat menguntungkan bagi peserta didik dengan gaya belajar audio, adapun pengontrolan yang dilakukan terhadap media pembelajaran sangat membantu bagi siswa yang menggunakan gaya belajar kinestetik, dengan demikian gabungan dari beberapa media tersebut yang kemudian membentuk menjadi multimedia sangat membantu bagi berbagai gaya belajar tersebut.

Multimedia yang didesain dalam pembelajaran mempunyai manfaat yang baik dalam pembelajaran, karena selain memadukan beberapa unsur media yang terkontrol untuk mencapai tujuan pembelajaran, juga multimedia yang dibuat tersebut dilaksanakan melalui perencanaan yang matang. Perencanaan yang matang ini lah semua aspek yang digunakan akan menggunakan rancangan pembelajaran ini mempertimbangkan, terutama dalam keberagaman gaya belajar siswa karena hal inilah salah satu tujuan dari multimedia yang dalam pembelajaran.

Dilihat pada bagan di atas bahwa multimedia memadukan beberapa media pembelajaran, seperti media foto hal ini sangat bermanfaat bagi peserta didik yang mempunyai gaya belajar audio, begitu juga media pembelajaran audio yang sangat menguntungkan bagi peserta didik dengan gaya belajar audio, adapun pengontrolan yang dilakukan terhadap media pembelajaran sangat membantu bagi siswa yang menggunakan gaya belajar kinestetik, dengan demikian gabungan dari beberapa media tersebut yang kemudian membentuk menjadi multimedia sangat membantu bagi berbagai gaya belajar tersebut.

\begin{tabular}{|c|c|}
\hline 1 Prtaingen hehurı & 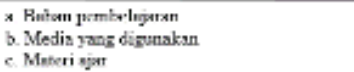 \\
\hline 2. Pertimbangan & $\begin{array}{l}\text { 3. Karakteristik siswa dan Gava belajar siswa } \\
\text { c. Keschisan fasilitas }\end{array}$ \\
\hline 3. Pemburten & 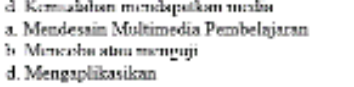 \\
\hline
\end{tabular}

Rancangan di atas memberikan pemahaman lebih jelas bagi pendidik dalam mendesain pembelajaran berbasis multimedia memperhitungkan semua aspek pada saat proses pembelajaran, salah satunya yaitu kesediaan bahan ajar serta kesesuaian materi ajar dengan media yang digunakan dan juga penggabungan beberapa media pembelajaran yang digunakan serta dapat 
bekerja secara bersamaan (sinergis) untuk mencapai tujuan pembelajaran yang akan di capai.

Pembelajaran yang dapat menerima dan memahami karakter dan cara belajar peserta didik akan membuat tertarik anak didik. Oleh karena itu, rancangan pembelajaran berbasis multimedia, bisa jadi terkesan dapat memahami keberagaman peserta didik. Namun, dalam mendesain pembelajaran tersebut pendidik memang betul-betul mempersiapkan dengan baik agar pembelajaran dapat berjalan dengan efektif dan efisien.

Pembelajaran ini, dalam kenyataannya di Indonesia baru sedikit di terapkan, terutama hanya dalam perkotaan saja yang bisa menerapkan pembelajaran berbasis multimedia ini. Upaya penyempurnaan terus dilakukan, juga komponen-komponen kesediaan semua media terus di upayakan agar disanggupi. Oleh karena itu, pembelajaran berbasis multimedia ini memang sangat belum memungkinkan untuk dilakukan dapa perkampungan yang listrik saja susah untuk mendapatkan apalagi bermacam-macam media yang bisa digabungkan sehingga dapat bekerja sama mencapai tujuan pembelajaran.

\section{Upaya Memahami Keberagaman Gaya Belajar Anak}

Penjelasan di atas telah menunjukkan bahwa dalam pembelajaran berbasis multimedia yaitu dengan menggabungkan beberapa media pembelajaran seperti, gambar, audio, anime, film dan lain sebagainya. Dalam menyajikan suatu materi pendidik menggunakan beberapa media tersebut atau guru tidak monoton dalam penggunaan media, misalnya hanya gambar saja atau teks saja.

Dalam pembelajaran berbasis multimedia yang digunakan oleh pendidik. Proses Belajar Mengajar (PBM) dirancang dengan sedemikian rupa sehingga mampu menampung berbagai keberagaman gaya belajar siswa. Depdiknas, dalam penjabaran tentang prinsip PBM berpusat pada siswa bahwa proses belajar mengajar, alat belajar, materi belajar, sesuai karakteristik peserta didik. PBM perlu menempatkan siswa sebagai subjek belajar. Artinya, PBM yang dilaksanakan memperhatikan gaya belajar yang cenderung digunakan oleh siswa. PBM juga perlu mendorong siswa mengembangkan potensi yang ada dalam dirinya. Hal ini yang terdapat pada rancangan pembelajaran berbasis multimedia di atas.

Dengan demikian, pembelajaran berbasis multimedia dapat dikatakan mampu memahami keberagaman gaya belajar siswa. Pembelajaran dirancang secara sistematis dengan memadukan beberapa media pembelajaran sehinga dapat berjalan secara sinergis demi mencapai tujuan pembelajaran. Peserta didik dengan riang dan gembira mengikuti proses pembelajaran karena dapat memenuhi karakteristik dan gaya belajar mereka. Jadi, pembelajaran berbasis multimedia ini akan semakin menguat dan memberdayakan gaya belajar masing-masing anak.

\section{KESIMPULAN}

Berdasarkan hasil pembahasan di atas, disimpulkan bahwa merancang pembelajaran berbasis multimedia tidak sulit dan dapat menunjang pembelajaran. Upaya yang dilakukan dalam mendesain pembelajaran berbasis multimedia tersebut dapat memahami keberagaman belajar peserta didik, sehingga ketika suatu pembelajaran dapat memahami karakteristik dan gaya belajar siswa, pembelajaran diharapkan dapat berjalan lebih efektif dan efisien.

\section{DAFTAR PUSTAKA}

Beydogan, H. O., \& Zelnel Hayran. (2015). The Effect of Multimedia-Based Learning on the Concept Learning Levels and Attitudes of Students. Eurasian Journal of Education Research, Issue 60, 261-280.

Bire, A. L., Geradus, U., \& Bire, J. (2014). Pengaruh Gaya Belajar Visual, Auditorial, dan Kinestetik Terhadap Prestasi Belajar Siswa. Jurnal 
Kependidikan: Penelitian Inovasi Pembelajaran, 44(2)

https://doi.org/10.21831/jk.v44i2.5307

Binanto, Iwan, (2010), Multimedia Digital:

Dasar Teori dan Pengembangannya, Yogyakarta: Andi Offset.

Bobbi DePorter, Mark Reardon, Sarah Singer-Nourie, (1999), Quantum Teaching: Orchestrating Student Success, Boston: Allyn and Bacon. Terjemahan Ary Nilandari, (2008), Quantum Teaching: Mempraktikkan Quantum Learning di Ruang Kelas. Bandung: Mizan Pustaka

Butcher, K. R. (2006). Learning from Text with Diagrams: Promoting Mental Model Development and Inference Generation. Journal of Educational Psychology, 98(01), 182-197. https://doi.org/10.1037/00220663.98.1.182

Departemen Pendidikan Nasional, (2008), Kamus Bahasa Indonesia, Jakarta: Pusat Bahasa.

DePorter, B., \& Mike, H. (2010). Quantum Learning (A. Abdurrahman, Penerj.). Bandung: Kaifa.

Gunawan, G., Harjono, A., \& Imran, I. (2016). Pengaruh Multimedia Interaktif dan Gaya Belajar Terhadap Penguasaan Konsep Kelor Siswa. Jurnal Pendidikan Fisika Indonesia, 12(2), 118-125. https://doi.org/10.15294/jpfi.v12i2.501

Halim, A. (2012). Pengeruh Strategi Pembelajaran dan Gaya Balajar Terhadap Hasil Belajar Fisika Siswa SMPN 2 Secanggang Kabupaten Langkat. Jurnal Tabularasa PPS UNIMED VOL. 9 No. 2, 141-159.

Hermawan, Irwan, (2017), Pengaruh Penggunaan Multimedia Presentasi Terhadap Peningkatan Kemampuan Mengklasifikasikan Tumbuhan Sebagai Obat Tradisional, Journal Teknologi Pendidikan dan Pembelajaran Sekolah Tinggi Keguruan dan Ilmu Pendidikan Garut, Volume 2, Nomor 1, h. 27-38.

Khodijah, Nyanyu (2014), Psikologi Pendidikan, Jakarta: RajaGrafindo Persada.
Mayer, R. E. (2009). Multimedia Learning: Psrinsip dan Aplikasi (T. W. Utomo, Penerj.). Yogyakarta, Indonesia: Pustaka Pelajar.

Mayer, R. E., Bove, W., Bryman, R., Mars, R., \& Tapangco, L. (1996). When less is more: Meaningful learning from visual and verbal summaries of textbook lessons. Journal of Educational Psychology, 64-73.

Moreno, R., \& Mayer, R. E. (1999). Multimedia-Supported Metaphors for Meaning Making in Mathematics. Cognition and Instruction, 17(3), 215248.

https://doi.org/10.1207/S1532690XCI17 03_1

Moreno, R., \& Valdez, A. (2005). Cognitive load and learning effects of having students organize pictures and words in multimedia environments: The role of student interactivity and feedback. Educational Technology Research and Development, 53(3), 35-45. https://doi.org/10.1007/BF02504796

Provenzo, E. F. (1986). Larry Cuban. Teachers and Machines: The Classroom Use of Technology since 1920. New York: Teachers College Press, 1986. Pp. $\mathrm{x}$, 134. \$9.95. History of Education Quarterly, 26(4), 647-648. https://doi.org/10.2307/369036

Raiz, Muh (2015), Pengaruh Penggunaan Multimedia Presentasi Berbasis Prezi dan Gaya Belajar Terhadap Kemampuan Mengingat Konsep, Jurnal Media Komunikasi Universitas Negeri Makassar, Volume 2, Nomor 1, h. 1024.

Rosyidah, L. (2017). Hubungan golongan darah dan gaya belajar dengan hasil belajar siswa pada mata pelajaran Matematika (Undergraduate, UIN Sunan Ampel Surabaya). Diambil dari http://digilib.uinsby.ac.id/19193/

Rudi\&Cepi, (2007), Media Pembelajaran, Bandung: Wacana Prima.

Sanjaya, W. (2012). Media Komunikasi Pembelajaran. Bandung: Fajar Interpratama. 
Slameto, (1995), Belajar dan Faktor - Faktor

Belajar yang Mempengaruhi, Jakarta: Rineka Cipta.

Suryadi, (2010), Psikologi Belajar Pendidikan Usia Dini, Yogyakarta: Bintang Pustaka Abadi

Suyono dan Hariyanto, (2012), Belajar dan Pembelajaran: Teori dan Konsep, Bandung: Remaja Rosdakarya.

Tsingos, C., Bosnic-Anticevich, S., \& Smith, L. (2015). Learning styles and approaches: Can reflective strategies encourage deep learning? Currents in Pharmacy Teaching and Learning, 7(4), 492-504.

https://doi.org/10.1016/j.cptl.2015.04.00 6

Uno, Hamzah B. (2008), Orientasi Baru Dalam Psikologi Pembelajaran, Jakarta: Bumi Aksara.Vaughan, T. (2010). Multimedia: Making It Work, Eighth Edition (9 ed.). McGraw Hill Professional.

Yuniawatika, Y. (2018). Learning Style of Grade V Students At Elementary Schools In Blitar. KARYA DOSEN Fakultas Ilmu Pendidikan UM, O(0). Diambil dari http://karyailmiah.um.ac.id/index.php/karya-dosenfip/article/view/75991

Zang, Dongsong (2015), interactive Multimedia-Based E-Learning: A Study of Effectiveness. The America Journal of Distance Education, Volume 19. Nomor 3, h. 149-162. 